\title{
N89-11262
}

FEATURE ARTICLE:

tutorials, and surveys

\author{
A COMPARATIVE OVERVIEV OF MODAL TESTIMG AN \\ SYSTEM IDENTIFICATION FOR CONTRO OF STRUCTURES
}

J.-N. Juang* and H.S. Pappa*

\begin{abstract}
This paper presents a comparative overview of the disciplines of modal testing used In structural engineering and system Identiflcation used in control theory. A IIst of representative references from both areas is given, and the baslc methods are described brlefiy. Recent progress on the Interaction of modal testing and control disciplines is discussed. It is concluded that combined efforts of researchers in both disciplines are requlred for unification of modal testing and system identification mothods for control of flexible structures.
\end{abstract}

Modal testing in the field of structures means the process of measuring signals produced by a structure and identifylng modal parameters (damplng, frequencles, mode shapes and modal particlpation factors). System identification in the fleld of controls means the process of measuring signals produced by a system and bullding a model to represent the system for control design. Technlques to identlfy a model from measured data typlcally contaln two steps. First, a family of candidate models is chosen and then the particular member in this famlly is determined whlch satisfactorlly describes the observed data based on some error criterion. If the identifled model is a I inear model in state space representation, the elgensolution of the model provides el gemalues and elgenvectors that, in turn, determine modal parameters for structures. Correl ation between the fields of modal testing and system Identiflcation for controls is evident.

The area of modal testing is a well-developed disclpl ine with strong experimental foundations $[1-76]$. The area of system identification for controls is well-developed ith sol id theoretical and methodologlcal foundations [77-170]. While the development of each Individual area continues, there is a need to provide a comprehenslve yet coherent unification of the areas. Active control of flexible structures will require the combined efforts of researchers in both disciplines. Among these chal lenges is control of large space antennas and platforms.
The areas of modal testing and system identification encompass a multitude of approaches, perspectives and techniques whose interrelaFonsh ips and relative merlt are difficult to :iort out. As a result, it is difficult for a nonspeciallist to extract the fundamental concepts. It may take consi derable effort to gain anough intuition about a particular technique $\rightarrow$ be able to use it ef fectively in practice.

he objective of this paper is to present an ivervlew of the paral lel histor lcal development is modal testing used in structural englneering and system identification used in control heory. A list of princlpal references is rovided for studying the similarities and ilfferences among the many approaches in both areas.

\section{MOON TESTING}

This section contains a synopsis of the fleld of modal testing. The following three items are provided: (1) a conclse, yet complete, chronology of key developments that have occurred over the 40-year history of modal testing. (2) a br lef summary of currentiy used approaches, and (3) a chronological reference list of key publlcations.

The subject of modal testing has evol ved contincously since the $1940^{\prime} \mathrm{s}$, and an extensive i iterature has been generated (for example, note the bibllographles on Pp 1659-1734 in Proceedlngs of the 4th Internatienal Modal Analys ls conference, February 1986). It is beyond the scope of this paper to discuss all th is activity. Interested readers are referred to these references, or to several other morecomplete overvlews which have been written recently $[51,53,64,74,75]$, for additional information.

Chronology of Key Dovelopments. The chronol ogy is divided into three separate eras: pre-1970, 1970-1979 and 1980-present. The start of the

\footnotetext{
* MASA Langley Research Conter, Hampton, Virginla 23665
}

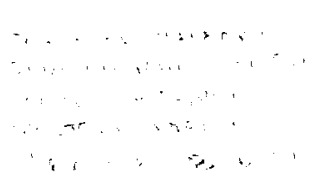


second and third eras accompanied significant Improvements in computer technology. The second era began with the widespread introduction of minicomputers (e.g., PDP-11) and the third with the availabllity of much larger and faster computers for laboratory data analysls (e.g., VAX or mainframes).

In the first era of modal testing, from approximately 1940 through 1969, analog techniques were used almost exclusively. Laboratory computers were nof yet avallable, and mainframe computers were used only rarely for data analysls. Much of the earl lest work occurred in the alrcraft industry, where testIng was conducted to check the accuracy of calculated normal modes used in flutter and dynamlc loads predictions. The two most significant contributions from this perlod were the works of Kennedy and Pancu [1], who introduced "circle fitting' for decomposing trequency response functions (FRF's) into the constituent modes, and Lew is and Wrisley [2], who described a systematic approach for tuning Individual modes using multiple shakers and apportioned sinusoldal excitation. These two technlques, with numerous varlations, were used in the majority of modal tests conducted prlor to 1970. Testing was very time consuming. however, and requi red consl derable practl ce and sklll for success. All laboratory equipment was analog, and most data analysis was performed by hand.

The second era occurred during the 1970's, sparked by the introduction of laboratory minloomputer systems $[15,19]$ and the fast Fourler transform algor ithm to compute frequency response functions $[18,30]$. Compared with the classical method of slowly sweeping a sinusoldal signal to generate FRF's, these systems offered tremendous speed advantages. They were widely adopted by the modal testing communlty, with the exception of those organlzations that had al ready made I arge I nvestments in multiple-shaker sinusoldal testing equipment. The minlcomputer in these laboratory systems was used not only to compute FRF's, but al so for curve fitting the FRF data to estimate modal parameters. Many of the analysis techniques used during this perlod, however, were simply digital versions of techniques devel oped earller (e.g., clrcle fltting or phase separation techniques). Thls situation began to change durling the second hal $f$ of the 1970 's in conjunction with the avallabllity of more powerful processors [31]. Also, the use of malnframe computers for data analysis was beglnning to occur $[34,35]$. There was considerable hesltancy to use malntrames, however, because of the expense and because most analysis techniques in use at the time required considerable interaction with the user.
Ths third era of modal testing began around 19.30, again in conjunction with improved computers and data acquisition equipment. One of tha most significant changes occurred in the use of multiple-input random excitation [42], rather than the single-input random approach prevlously used most often. Multiple-input exilation provides several advantages: (1) it is consistent with multiple-reference (multipla-input) modal identification algorithms $[49,55,60,61,67]$ wh lch al low closely spaced modes to be better 1 dentifled. (2) $1+\mathrm{m}|\mathrm{n}| \mathrm{m} \mid z$ es troublesome shifts in frequency and mode shapes which can occur when exclters are moved to different points on a structure, and (3) it is slgnificantly faster whenever several different locations and directions of excitation are needed to excite al I the modes of interest. which is usually the case. In conjunction with multiple-input methods, Improved methods of excitation $[54,56]$, signal processing $[65]$, frequency response calculation [59], and quick deta analysis $[66,69]$ have al so been Introduced. Renewed attention is being given to AFMA-type analysis techniques [72] which were studied years earl ler $[11,13,35]$ and general ly thought to be too computational ly extensive for the volume of data obtalned in modal tests (often $>20$ modes and $>100$ measurements). Faster and more powerful computers now make these af proaches more practical. Faster computers al so permit nonlinearities to be better detected and identifled, using new signal processing techniques [57]. Nonl inearitles are al so beling better quantifled using modern stepped-sine excitation techniques. In conjunction with new modal identification algor ithms wh ish can use unequal ly spaced frequency data [0]. Renewed interest is al so occurring in the classical forced normal mode approach to modal testing. However, today the excltation tuning process is belng computerlzed more than ov er [76].

Current Methodology. As dlscussed above, modal testing methodology has changed conslderably $\alpha$ er the years -- and $1+$ continues to change. There are now many different ways to conduct testing and data analysis. Essential ly all technlques work well with slmple structures, yot slgnificant differences occur when used on amplex, bullt-up structures. It is still ot ten difflcult to deduce the exact source of these differences, however, because the "true" allswers are unknown with experimental data. Butter methods for comparing varlous identificition technlques with complex data are needed [11], as are methods for conduct Ing more realistic and thorough simulations of complex structural behavior to generate data for these sudies. To a large degree, the techniques used most often today are those which have demonstrated repeatedly thel $r$ tolerance of the amplexities of real data. 
Figure 1 provides an estimate of the general types of excltation and analysls now belng used in the modal testing community in the United States (the percentage of multi-input tuned sine dwell testing is much higher in Europe). Multiple-input random excitation is now very popular. It is estimated that $45 \%$ of all laboratory modal tests are belng conducted this way. Still very popular is the simpler, traditional single-input random approach ( $30 \%$ ). The percentage of people using multi-input tuned sine dwell (forced normal mode) testing has been falling since around 1975 and is estimated to be about 10\%. Of these, approximately one-hal $f$ are now using computers to generate opt Imum tunlng patterns. A smal I percentage of tests (5\%) are al so conducted using natural amblent excltation forcos (e.g., wind on bulldlngs, waves on of fshore oll platforms), usual ly because artificlal excitation is impractical. In many cases, the identification results from these tests are mush more ambiguous than those from control led-excitation tests.
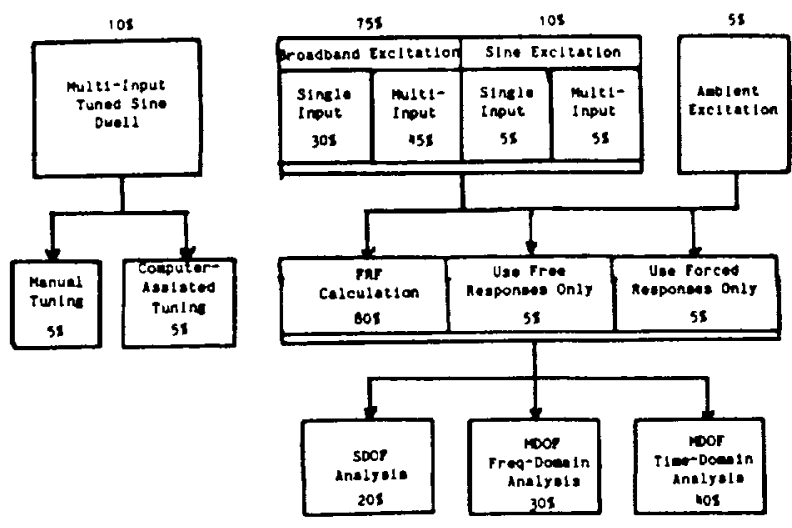

Figure 1. Current U.S. Modal Test Methodology Preferences (Estimated).

In the vast majorlty of testing ( $80 \%)$, fre quency response functions are computed prior to using a modal identification algor ithm. There are many reasons why FRF's are still generated so often, al though there are now many identification algorlthms avallable whlch can analyze free- or forced-response time historles directly. A significant factor is tradition: experlenced modal testing personnel can deduce conslderable information simply by observing frequency response functions. If time historles are processed directly by the modal iden tification algorithm, many traditional eval uation criter la are unavall able. The intermedlate step of calculating FRF's will probably be skipped more often in the future as more experience and confidence is galned with the newer, direct analysls approaches.
For modal identlfication, multi-degree-of1 reedom (MDOF) time-domain al gor ithms are beling ised the majority of the time (40\%), fol lowed by MDOF frequency-domain (30\%), and faster ingle-degree-of-freedom (SDOF) algorlthms (20\%). In most cases, the data used by the HDOF time-domaln algor ithms are impulse re:ponse functions obtained by inverse fourler ransformation of FRF's. Only in a few isoated instances are free-response data beling used directly. MDOF time-domaln algorithms :tIll appear to be unsurpassed in thelr ability o analyze wideband data w ith many modes, whlle heir frequency-domain counterparts have been ubserved by some people to be more accurate over narrow frequency bands, or when dampling is el atively high (e.g., greater than 5\%).

\section{SYSTEM IDENTIFICATION USED IN CONTRO THEORY}

Since the mid-1960's the field of system idenification has been an important discipline ith in the automatic control area. One reason s the requirement that mathematical models within a speclfied accuracy must be used to apply modern control methods. Another reason is the avallabllity of digltal computers that an perform complex computations. It is not the alm of this paper to present a detalled analysis of ach levements in this continuously jrowing $f$ leld or to glve the state-of-the-art. jee references [77-1 10$]$ for more detalls.

"requency and time domain methods give complenentary vlews of many important problems in linear system theory and control theory. Sometimes, the two methods have been seen as riral s, particularly on issues of Implementation and appl lcation to real systems. Histor 1ally, frequency domain methods dominated theory and practice of system identification in control engineerling prior to the 1960's.

Frequency Domain Approach. Frequency domain identiflcation in control engineering gained relevance with stablility and design methods based on frequency response measurements. Frequency response estimation began with the technique known as transfer function analysis. The sinusoldal transfer function analyzer is recognized as a robust and practical ly useful non-parametric identification method. This is due to the Intrinsic rel labllity with which the sinusoldal transfer function analyzer is able to reject low-frequency drift and harmonic distortion due to nonl inearity. However, the slnusoldal transfer function analyzer requlres long test times to sequential ly identify each relevant point on a frequency response curve. A more widely used class of techniques has been developed around digltal spectral analysis and numerlcal fourler transforms. The Impact of the Fast Four ler Transform (FFT) developed by cooley and Tukey [113] upon digltal and analog 
spectral analysis was enormous. The FFT actually encompasses a whole family of algor ithms, many of which are included in the institute of Electrical and Electronlcs Engineers (IEEE) collected reprint written by Rabiner and Rader [117]. Modern digital spectral analysis, real time or of $f-1$ ine, is normal ly achleved by the direct method which takes the FFT of data blocks and then averages the resulting spectral estimates.

The direct estimation scheme can al so be applled to determine estimates of frequency response functions by using a closed loop system design. The normal open loop system deslgn may give blased results with physically unreal izable frequency response estimates. A closed loop system design may improve this situation, leading to gain and phase estimates which are well behaved, provided that careful attention is pald to windowing and al lasing. A more precise discussion of the accuracy of closed loop estimates is given in Daval I [119], and Wel Istead [122].

The maximum entropy method (MEM) of spectral analysis wos orlginated by Burg [114] for analyzing geophyslcal data, and further developed by Ables [1 18] and Ulrych and BIshop [120]. The baslc phllosophy of the method is to construct spectral estimates that are consistent with all relevent data and are maximal ly non-committal with regard to unavallable data. The maximum entropy method generally glves superior spectral resolution to traditional methods at the expense of increased varlabllity, and posslbly erroneous splitting of spectral lines observed by Fougere, etc. [121].

Frequency domain identification, which, in the past, emphaslzed non-parametr ic identification, i.e., frequency response estimation, has lost popularity in recent years. This is due to the fact that current control synthesls and design tools require parametric system models such as a state space representation, stochastic difference equation or generalized regression model. If a spectral onalysis or transfer function analysis experiment is conducted, least squares can be used to fit a parametrlc frequency response model by assembling a set of $\mathrm{N}$-measured trequency response polnts and solving the unknown coefficlents of the transfer function model $[112,115,123]$. However, these fitting methods may produce poor models which may not represent the underlying system well enough for controller design, partlcularly for complex structural dynamics problems. To a I Imited degree, these shortcomings are beling investigated by current work on combined iden tIflcation and control. Indeed, the pole-zero assignment technique developed by Kel Istead, et al. [124] seems to of fer qualities of robust- nuss. The technlque developed by Juang and Sizuk I [168], which uses estimated frequency sectra to identify a state space model in midal space vla system real ization theory, al so seems to offer a good model for control design.

Timo Domaln Approach. The time domaln approach has dominated the control engl neerling literature on system identification over the past 20 y)ars. In this section, a general description o: commonly used I inear system identification mathods will be given. Time domain approaches are categorized according to the cholce of midel and the cholce of identification criterion for evaluating the estimation quality. Basic methods are given in the references.

Tie orlgin of the least squares method can be t-aced to Gauss [125] who formulated the baslc concept and used it practically for astronom 1cal computation. Since then, it has been widely appl led to many problems. The recursive algor ithm to calculate the least squares est 1mate has apparently been found Independently by saveral authors. The or Iglnal reference seems to be Plackett $[128]$. An early and thorough t-eatment of the least squares method appl led to dynamic system identification is given by Astrom [94]. The statistical background for stochastic approximation was developed by Fobbins and Monro [129]. Stochastic approximation methods have al so been derlved by Sakr Ison [138]. Computational algor ithms are based on stochastlc gradient methods for I lnear regresslon models. In LJung [161] the stochastic approximation approach is used to derlve recursive identification algorithms for problems cther than I Inear regression models.

The Kalman-Bucy filter [132] is a state est Imator. It is Mayne [134] who draws attention to extending the Kalman-Bucy fllter for parameter estimation of a state space model. The basic I dea of the instrumental varlable method (e.g., Kendal and Stuart [133] and Young [143]) is the ceneration of an extra slgnal, l.e.. the inctrumental varlable, which is correlated with the useful signals of the process but which is incorrelated with nolse. This el iminates the lias error assoclated with least squares estiration. Recursive instrumental varlable methcids have been used extensively by Young [153].

The characteristics of nolse corrupting the cutput of the system may not be well known. In the general ized least squares method, the larameter estimates may include estimates of liolse parameters. Insplred by Clarke's algolithm [139] for general ized least squares analysis, a recursive method was suggested by Hasting-james and Sage [142]. The princlple of extended least squares is that the calculation of the error between the true output and the astimated output is based on past estimates of 
system and nolse parameters. The extended least squares algor Ithm was independently derived by Panuska [140] and Young [141] and widely used and rediscovered by Talmon and van den Boom [149]. In many practical problems of parameter estimation the problems arlses of solving an overdetermined 111 -conditloned set of algebralc equations. To clrcumvent this problem, the error covariance matrix can be propagated in a square root form so that the posltive seml-definite nature of the error covarlance is malntalned to minlmize the complexity of the statistical properties of the error estimates. A survey of square-root flltering techniques was given by Kaminski, et al. $[146]$.

The baslc idea of maximum-l ikel ihood estimation is to construct a function of the data and unknown parameters called the l lkel thood function. The likel thood function is essentially the probabllity density of observations. The estimate of parameters is then obtalned as the parameter set which maximizes this function. The method of maxlmum I lkel lhood was developed by Fisher $[126,127]$ al though the basic idea dates back to Gauss [125]. In the Bayesian approach, the parameters themsel ves are treated as a random varlable. Based on observations of other random varlables that are correl ated with the parameter, information about its value can be Inferred. Therefore, the parameter estimate Is expressed in terms of the probabllity distribution conditioned by past history.

Ho [135] showed that the instrumental varlable method, general lzed least squares and extended least squares are closely rel ated to stochastlc approximation and Kalman-Bucy flltering. Actual ly, square-root filtering belongs to the same famliy, as well, but the computational concept differs essentlally. For I lnear systems and Gaussian nol se, the maximum- l lkel lhood approach ylelds the same conditions for the parameter calculation as the least-squares approach. Although the preceding technlques have been widely used in the field of controls, formal direct application to modal parameter Identification for flexible structures has been $\mathrm{m} \mid \mathrm{nl}$ mal. Two techniques which has been extended and applied for modal Identification of structures -- minimum realization and lattlce filtering -- are discussed in the following section.

Techniques Related to Modal Testing. In the fleld of controls, the process of constructing a state space representation using exper imental data is called system realization. A minimum realization is a model with the smal lest state space dimension among models real lzed that have the same input-output relations with in a speci$f$ led degree of accuracy. Minimum realization theory was origlnally developed by $\mathrm{Ho}$ and
Kilman [137], using Markov parameters (pulse rfsponse functions). Questions regarding $\mathrm{m} / \mathrm{n}$ Imum realization from varlous types of 1r put-output data and generation of a minimum pertial realization were studled by Tether [44]. SIlverman [145], and Rossen and Lapldus [47]. Rossen and Lapldus [148] successfully af pl led Ho-Kalman and Tether methods to chemlcil engineering systems.

A common weakness of the preceding schemes is that the effects of nol se were not evaluated. Arong follow-up developments along similar 1 nes, Kung [156] presented another algor ithm in conjunction with the singular value decompo$s$ tion technlque to treat the presence of the nilse. Under the interaction of structure and cuntrol disclplines, the Elgensystem Real Iza$t$ on Algorlthm (ERA) [61] was developed by Jiang and Pappa for modal parameter Identiflica$t$ on and model reduction for dynamlc systems f om test data. Based on a similar approach, a $f$ equency-domain ERA and a recursive ERA al so w re developed $[168,170]$. Thorough treatment $0^{*}$ the effects of nolse on the ERA-identified molal parameters was presented by Juang and P.ippa [167]. Correlation of several modal tisting methods was derlved by Juang [169] via sistem real ization theory.

Ladder or lattice filtering first appeared in t:e reviewed I Iterature by Morf, et al. [155] as a recursive method for solving the l Inear liast squares problem. The term "ladder" or "lattice" or I ginated from the shape of the data flow dlagram of the technique. Interpreted in terms of the corresponding state space real lzation, the ladder implementation uses a state vactor that has a diagonal covarlance matrlx. Fecursive identification using the ladder representation has been extenslvely studled by $L \theta \theta$ and Morf [159] and Frledlander [88]. fiecently, the algor ithms have been appl led to identlfication of flexible structures by Sundararajan and Montgomery $[162,164]$ and Wiberg $[165]$.

\section{CONQLDING REMMRS}

The fleld of modal testing has expanded contInuously over its 40-year history. Thls crowth is largely assoclated with corresponding improvements in computer capabllities. These increases in computer capabil ity have permitted more accurate and complete testling and data cnalysis to occur. Algorlthms and approaches thought $+\infty$ extensive in the past are now teaslble. Several new uses for modal test data tave al so evol ved. In particular, experimental nodal data are now beling used frequently to irectly solve the problem at hand, rather than cnly for refining a finite-element model, the traditional use in the aerospace community. hese direct uses of test data include predict- 
Ing the effects of physical changes to the structure using an experimental modal model and developing hybrid analytical/experimental models of overall system dynamics.

For active control of space structures, the experimental modal data can also be used directly for control law design, once the final configuration of the system is tested using the control sensors and actuators. This task will requi re complete and accur ate Identification of the system while in orblt and is motivating further technology improvements to ensure success. Complex, bullt-up structures, in particular, stlll pose a significant chal lenge to the best ground-based methodology now avallable. Success with large space structures will demand the combined efforts of the control and structural dynamics disciplines. The solld theoretical and methodologlcal foundations from the control field should be comblned with the extensive experimental know ledge from the modal testing field. Additional work is needed to better understand and correlate current techniques from both flelds. A principal goal is to find a common basis to explain and to select from the myrlad of possible technlques.

\section{REFERENCES}

\section{Modal Testing Literature} Pre-1970

1. Kennedy, C.C. and Pancu, C.D.P.. "Use of Vectors in Vibration Measurement and Analysis," J. Aero. Scl., 14 (11), Pp 603-625, (Nov 1947).

2. Lew is, R.C. and Wrisley, D.L.. "A System for the Excltation of Pure Natural Modes of Complex Structure," J. Aero. Scl.. 17 (11), pp 705-722. 735 ( Nov 1950).

3. Asher, G.W., "A Method of Normal Mode Excltation Utilizing Admittence Measurements," Proc. Nate Spec. Mto. Dyname and Aeroe lasticity, PP 69-76 (Nov 1958).

4. Tralll-Nash, R.W., "On the Excltation of Pure Natural Modes in Alrcraft Resonance TestIng," J. Aero. Scl.. 25 (12), pp 775-778 (Dec 1958).

5. Stahle, Jr., C.V., "Phase Separation Technlque for Ground Vibratlon Testing," Aerospace Engrg., pp 56-57, 91-96 (July 1962).

6. Bishop, R.E.D. and Gladwell, G.M.L.. "An Investigation into the Theory of Resonance Testing," Ph II. Trans. Roy. Soc. London, Serles A. Vol. 255. Pp 241-280 (Jan 1963).

7. Pendered, J.W., "Theoretical Investigation into the Effects of Close Natural Frequencles in Resonance Testing," J. Mech. Engrg. Scl., I (4), PP 372-379 (1965).

\section{$1970-1979$}

E. Klosterman, A.L., "On the Experimental Letermination and Use of Modal Representations cf Dynamic Characteristics," Ph.D. DissertatIon, Unlv. of Cincinnati (1971).

S. Favour, J.D., MItchel I, M.C., and OIson, A.L., "Translent Test Technlques for Mechanical Impedance and Modal Survey Testing," Shock Vib. Eull.. 42 (1), pp 71-82 (Jan 1972).

10. Cole, H.A., "On-Line Fall ure Detection and [ amplng Measurement of Aerospace Structures by Fandom Decrement Signatures," NASA CR-2205 (Mar 1973).

11. Gersch, W., Nlel sen, N. N., and Akalke, H., 'Maximum Likel ihood Estimation of Structural Farameters from Random Vibration Data," J. sound VIb., 31 (3), pp 295-308 (1973).

12. Cralg, Jr., R.R. and Su, Y-W.T., "On Multiple-Shaker Resonance Testing, "A IAA j., 12 (7), Pp 924-931 (July 1974).

13. Gersch, W., "On the Ach levable Accur acy of ctructural System Parameter Estimates," J. sound Vib., 34 (1), PP 63-79 (1974).

14. Van Loon, P., Modal Parameters of Mechanical Structures," Ph.D. DIssertation, rathol leke Universitelt Leuvan, Leuven, Bel gl um (1974).

5. Klosterman. A. and ZImmerman, R., Modal Survey Activity VIa Frequency Response Func+lons," SAE Paper 751068 (Nov 1975).

6. Knauer, Jr., C.D., Peterson, A.J., and Fendahl. W.B., "Space Vehicle Experimental Modal Def Inition Using Transfer Function Techilques," SAE Paper 751069 (Nov 1975).

7. Potter, R., "A General Theory of Modal hnalysis for Linear Systems," Shock Vib. Dig., j. (11). Pp 3-11 (Nor 1975).

8. Ramsey, K.A., "Effective Measurements for itructural Dynamics Testing: Part I," S/V, sound VIb., PP 24-35 (Nov 1975).

19. Richardson, M.H., Modal Analysis Using iligital Test Systems," Proc. of Semlnar on Inderstanding Digital Control and Analysis in Yloration Test Systems, Part 2, S.V.I.C. Publ., lip 43-64 (May 1975).

:0. Rich ardson, M.H. and Potter, R., "VIscous s. Structural Damping in Modal Analysis," shock VIb. Bull., 46 (Oct 1975). 
21. Salyer, R.A., Jung, E.J., Mugglns, S.S., and Stephens, S.L.. "An Autcmatlc Data System for Vibration Modal Tuning and Evaluation," NASA TN D-7945 (Apr 1975).

22. Sloane, E.A. and McKeever, B., MModal Survey Technlques and Theory," SAE Paper 751067 (Nov 1975).

23. Wada, B.K., "Modal Test: Measurement and Analysls Requlrements," SAE Paper 751066 (Nor 1975).

24. Hamma, G.A., Smith, S., and Stroud, R. C.. "An Evaluation of Excitation and Analysis Methods for Modal Testling," SAE Paper 760872 (Nov 1976).

25. Ibanez, P.. "Force Appropriation by Extended Asher's Method," SAE Paper 760873 (Nov 1976).

26. Klosterman, A.L., "Modal Surveys of Weakly Coupled Systems," SAE Paper 760876 (Nov 1976).

27. Leppert, E.L., et al., "Comparlson of Modal Test Results: Multipolnt Sine Versus SIngle Polnt Random," SAE Paper 760879 (Nov 1976).

28. Mustain, R.W., "Survey of Modal Vibration Test/Analysls Technlques," SAE Paper 760870 (Nov 1976).

29. Natke, H.G., "Survey of European Ground and FIIght Vibration Test Methods," SAE Paper 760878 (Nov 1976).

3C. Ramsey, K.A., "Ef fective Measurements for Structural Dynamics Testing: Part 11," Sound Vib., pp 18-31 (Apr 1976).

31. Stroud, R. C., Smith, S.. and Hamma, G. A.. "MODALAB: A New System for Structural Dynamics Testing," Shock VIb. Bull., 46 (5), PP 153-175 (Aug 1976).

32. Brown, D.L.. Carbon, G., and Ramsey, K. A., "Survey of Excltation Techniques Appl Icable to the Testing of Autamotive Structures," SAE Paper 770029 (Mar 1977).

33. Hal vor sen, W.G. and Brown, D.L., "Impul se Technlque for Structural Frequency Response Testing," Sound VIb., pp 8-21 (Nov 1977).

34. Ibrah im, S.R. and Mikulcik, E.C., MA Method for the Direct Identification of VibratIon Parameters from the Free Response," Shock vib. Bull., 47 (4), pp 183-198 (Sept 1977).

35. Pandit, S.M.. "Analysls of Vibration Records by Data Dependent Systems," Shock Vib. Bull., 47 (4), pp 161-174 (Sept 1977).
36. Fowler, J.R. and Dancy, E., "Transfer Function Appl ications to Spacecraft Structural [ynamlcs," Shock VIb. Bull.., 48 (1), pp 93-101 (1978).

27. Hanks, B.R., et al.. "Comparison of Modal Test Methods on the Voyager Payload, "SAE Paper 781044 (Nov 1978).

3. Morosow, G. and Ayre, R. S., "Force Apportioning for Modal Vibration Testing Using incomplete Excltation," Shock Vib. Bull., 48 (1), pp 39-48 (Sept 1978).

39. Stahle, C.V., "Modal Test Methods and hppl Ications," J. EnvIron. Scl.. pp 24, 33-35 (Jan/Feb 1978).

20. Stroud, R.C., Bonner, C.J., and Chambers, (i.J., Modal-Testing Options for Spacecraft [levelopments," SAE Paper 781043 (Nov 1978).

4. Brown, D.L., Al lemang, R.J., Zl imerman, P., and Mergeay, M., "Parameter Estimation echnlques for Modal Analysis," SAE Paper 90221 (Feb 1979).

\section{0-Present}

2. Al lemang, R.J., "Investigation of Some Multiple Input/Output Frequency Response Func* Ion Experimental Modal Analysis Technlques," Ph.D. Dissertation, Univ. Cincinnati (1980).

43. Anderson. J.E., "Another Look at SIneIwell Mode Testing," A IAA Paper 81-0532 (Apr (981).

44. Coppol Ino, R. M., "A Simultaneous Frequency Lomain Technique for Estimation of Modal Paameters from Measured Data," SAE Paper 811046 Oct 1981).

45. Pappa, R.S. and Ibrah Im, S.R., "A Parametic Study of the ITD Modal Identification Algor ithm," Shock Vib. Bull.. 21 (3), pp 43-72 May 1981).

16. Smith, W.R., "Least-Squares TIme-Domain Hethod for simultaneous identification of libration Parameters from Multiple Free-Response Records," AIAA Paper 81-0530 (Apr 1981).

17. Ewins, D.J. and Gleeson, P.T., "A Method for Modal Identlfication of Lightly Damped structures," J. Sound Vib., 84 (1), PP 57-79 (1982).

18. Leurlidan, J.M. and Kundrat, J.A., "Advanced MatrIx Methods for Experimental Modal Analysis -- A Multi-Matr Ix Method for Direct Parameter Extraction," Proc. 1st Intl. Modal Analysis Conf.. PP 192-200 (Nov 1982). 
49. Vold, H. . Kundrat, J.A.. Rockl In, G.T., and Russell, R., "A Multi-Input Modal EstimatIon Algor ithm for MInI-Computers," SAE Paper 820194 (Feb 1982).

50. Vold, H. and Rockl in, G.T., "The Numerlcal Implementation of a Multi-Input Modal Estimation Method for Mini-Computers," Proc. Ist Intl. Modal Analysis Conf.. Pp 542-548 (Nov 1982).

51. Al lemang, R.J., "Exper Imental Modal Analysis," Modal Iesting and Model Refinement, Dav Id F.H. Chu (Ed.), ASME AMD, 59 PP 1-29 (Nov (983).

52. Crowley, J.R., Peterson, E.L., and Russell, R., Multiple-lnput Method Speeds Space Shuttle Testing," $S / V$, Sound VIb., pp 14-20 ( June 1983).

53. Ewins, D.J., Modal Testing: Theory and Practice, John Wiley and Sons, Inc., New York (1984).

54. Hunt, D.L., Peterson, E.L., Vold, H. . and WIIIIams, R., "Optimal Selection of Excltation Methods for Enhanced Modal Testing," A IAA Paper 84-1068 (May 1984).

55. Leur Idan, J.M., "Some Direct Parameter Model Identification Methods Appl lcable for Multiple Input Modal Analysis," Ph.D. DissortatIon, Univ. Cinclennatl (1984).

56. Olsen, N.L.. "Excitation Functions for Structural Frequency Response Measurements," Proc. 2 nd $I n+1$. Modal Analysls Conf., pp 894902 (Feb 1984).

57. Simon, M. and TomIInson, G.R., "Appl Ication of the Hilbert Transtorm In the Modal Analysis of Linear and Non-LInear Systems," J. Sound VIb., 20 (2), PP 275-282 (1984).

58. Stroud, R.C., "The Modal Survey of the Gal Il eo Spacecraft," $S / V$. Sound VIb., pp 28-34 (Apr 1984).

59. Vold, H. . Crowley, J.R., and Rockl In, G.T., "New Ways of Estimating Frequency Response Functions, S/V. Sound V/b., PP 34-38 (Nov 1984).

60. Cralg, Jr., R.R. and Blair, M.A., "A General ized" Multiple-input, Multiple-Output Parameter Estimation Algorithm," AlAA J., 23 (6), pp $931-937$ (June 1985).

61. Juang, J.N. and Pappa, R.S.. "An Elgensystem Realization Algor Ithm for Modal Parameter Identification and Model Reduction," J. Guidance, Control Dynam., PP 620-627 (Sept-Oct 1985).
62. Leurldan, J.M., Brown, D.L. and All lemang, F.J., "TIme Domain Parameter identlfication Nethods for LInear Modal Analysls: A Unifyling Approach," ASME Paper 85-DET-90 (Sept 1985).

63. Rlchardson, M.H. and FormentI, D.L., "Global Curve Fitting of Frequency Response Neasurements Using the Rational Fraction Polyromlal Method," Proc. 3rd Intl. Modal Analysis Conf., Pp 390-397 (Jan 1985).

64. Stroud, R.C.. "Excltation, Measurement, and Analysis Methods for Modal Testing," iSCE/ASME Jolnt Mechanlcs Conf.., Al buquerque, M.M ( June 1985).

65. Taber, R.C., Brown, D.L., Vold, H., and Fockl in, G.T., "Exponentlal Window for Burst Fandom Excitation," Proc. 3rd Intl. Modal inalysis Conf., pp 989-995 (Jan 1985).

66. Willlams, R., Crowley, J.R., and Vold. H., "The Multivarlate Mode Indicator Function in Modal Analysis," Proc. 3rd intl. Modal Analysls Conf., pp 66-70 (Jan 1985).

67. Zhang, L., Kanda, H., Brown, D.L., and Allemang. R.J., "A Polyreference Frequency [omain Method for Modal Parameter Identificat lon," ASME Paper 85-DET-106 (1985).

6.8. Zlmmerman, R. and Hunt, D.L., "Mult|plenput Excltation Using Burst Random for Modal esting," S/V. Sound VIb., PP 12-21 (0ct 1985).

6. Brll lhart, R. and Hunt, D.L., "Computation cf Total Response Mode Shapes Using Tuned Frequency Response Funct lons," Proc. 4 th intl. Modal Analysis Conf.. PP 1228-1236 (Feb 1986).

7. Lembregts, F., Leurldan, J.M., Van der Auweraer, H., and Sas, P.. "Integrated Stepped Sine Modal Analysis," Proc. $11^{\text {th }}$ Intl. Sem Inar Hodal Analysls, Kathol leke Universitelt Leuven. Paper Al-1 (Sept 1986).

1. Pappa, R.S. and Juang, J.N., "Studles of Modal Identification Performance Using Hybr io llata," Proc. 3rd SDRC I-DEAS User's Conf., PP 15-129 (Oct 1986).

2. Prevosto, M., Ol agnon, M., and Benveniste, A.. "ARMA Modelization: A Sol ution to Modal Parameter Estimation," Proc. 11 th Intl. Sem Inar Modal Analysis, Kathol leke Universiteit Leuvan. Paper W1-3 (Sept 1986).

3. Vold. H., "Orthogonal Polynomlals in the Polyreference Method," Proc. 11th Intl. Sem Inar Ldal Analysis, Kathol leke Unlversitelt Leuven, Paper W1-9 (Sept 1986). 
74. Al lemang, R.J. and Brown, D.L., Modal Analysls: Twenty Years Back -- Twenty Years Ahead," S/V. Sound VIb., PP 10-16 (Jan 1987).

75. Ewins, D.J., "Uses and Abuses of Modal Testling," S/V, Sound Vib., pp 32-39 (Jan 1987).

76. Hunt, D.L.. Mathews, J., and WIIIIams, R., "A State-of-the Art Implementation of Multiple Input Sine Excltation," Proc. 5th intl. Modal Analysis Conf. (Apr 1987).

\section{Control Englneering Literature Survey Papers}

77. Eykhoff, P., "Process-Parameter Estlmatlon," In R.H. Macm Il lan (Ed.), Progress in Control Engineering. 2. Hey wood, London (1964).

78. Eykhoff, P., Van der Grinten, M.E.M.. Kwakernaak, H.. and Veltman, B.P.Th.. "System Modelling and Identlfication." IFAC congr.. London (1966).

79. Cuenod, M. and Sage, A.P.. "Comparlson of Some Methods Used for Process Identif Ication," IFAC Symp. on identification in Autamatic Control Systems, Prague, Paper 1 (1967).

80. Eykhoff, P., "Process Parameter and State Estimation," Automatlca, 4, p 205 (1968).

81. Young, P.C., "Process Parameter Estimation," Control, 12, p. 931 (1968).

82. Astrom, K.J. and Eykhoff, P.. "System Identification -- A Survey," Automatica, I, PP 123-162 (1971).

83. Strejc, V., "Least Squares in Identificetion Theory," Kybewrnetlka, 13, p 83 (1977).

84. LJung. L., "Convergence Analysis of Parametrlc identification Methods," IEEE Trans. Automatic Control, AC-23, p 770 (1978).

85. Strejc, V., "Trends in Identification," Automatica, 17 (i), pp 7-21 (1981).

86. Ljung, L. and Glover, K., "Frequency Domain Versus TIme Domain Methods in System Identification," Automatica, 17 (1), PP 71-86 (1981).

87. Wel Istead, P.E., "Non-Parametr ic Methods of System Identification," Autamatica, 17 (1), pp 55-69 (1981).

88. Frledlander, 8., "Lattice Filters for Adaptive Processing," IEEE Proc., 70 (8), Pp 829-867 (Aug 1982).

\section{Books}

89. Bartlett, M. S., An Introduction to Stochastic Processes. Cambridge Univ. Press, Cambridge (1953).

90. Anderson, T.W., An Introduction to Multivarlate Statistical Analysis, WIley, NY (1958).

9. Blackman, R.B, and Tukey, S.W., Measuremint of Power Spectra. Dover, NY (1959).

9?. Lee, R. C.K., Optimal Estimation. Identiflcation and control. M. I.T. Press, Cambridge, MA (1964).

95. Deutch, R., Estimation Theory, Prentice$\mathrm{Hal}$, Englewood Cliffs, NJ (1965).

94. Astrom, K.J., Lectures on the Ident If ication Problem - - The Least Squeres Method. Rept. 6306, Div. Autanatic Control. Lund Inst. Tech., Lund, Sweden (1968).

95. Dav les, W.D.T. , System ldentiflcation for Self-Adaptive control. Wiley-Intersclence, London (1970).

95. Rajbman, N. S., what is System identitication?. Nauka, Moscow (1970) (In Russian).

97. Sage, A.P. and Mel sa, J.L., System ldent1flcation, Academ lc Press, NY (1971).

98. Isermann, R., Experimental Analysis of Control System Dynamlcs and Theoretical Analys. Is, Bibl logr aph isches Inst., Mannheim (1971) (In German).

99. Mendel, J.M., Discrete Technlaues of Farameter Estimation, Marcel Dekker, NY (1973).

100. Lainlotis, D.G., Estimation Theory, El sevler, NY (1974).

101. Eykhof $t, P .$, System Ldentifleation, John Wlley \& Sons, London (1974).

102. Seinfeld, J.H. and Lapldus, L., Mathematical Methods in Chemlcal Englneering: Process Model ing. Estimation, and Ldentifica ion, Prentice-Hal l. Inc., Englewood Cl Iffs, NJ 1974).

03. Graupe, D., Ldentiflaation of System, Van vostrand, NY, First Edition (1971) and Kr leger Publ. Co.. Huntington, NY, Second Edition 1976).

104. Mehra, R.K. and Lalnlotis, D.G., (Eds.), system Identification Advances and Case StudLes, Academ IC Press, NY (1976). 
105. Goodwin, G.C. and Payne, R. L., Dynamle System Identification: Experiment Deslon and Data Analysls, Academ Ic Press, NY (1977).

106. Hsl a, T. C., Least Squares Metheds, LexIngton Books, Lexington, MA (1977).

107. Eykhof f, P., (Ed.), Irends and Progress In System Identification, Pergamon Press, Oxford (1980).

108. Iserman, R., (Ed.), Identlfication and System Parameter Estimation. Speclal Issue, Automatlca, 17 (1) (1981).

109. Ljung, L. and Soderstrom, T., Iheory and Practice of Recursive Identification, M. I.T. Press, Cambridge, MA (1983).

110. Chen, H.F., Recursive Estimation and control for Stochastic System, John WII ey \& Sons, NY (1985).

\section{Erequency Domain Papers}

111. Daniell, P.J., "Discussion on Symposium on Autocorrelation in TIme Serles," J. Roy. Stat. Soc., 8, p 88 (1946).

112. Levy, E.C., "Complex Curve Fitting," IEEE Trans. Automatic Control, AC-4, p 37 (1959).

113. Cooley, J.W. and Tukey, S.W., "An Algorithm for the Machine Calculation of Complex Four ler Series," Math. Comput., 12, pp 297-301 (1965).

114. Burg, J.P., Maximum Entropy Spectral Analysis," presented at the 37th Annual Intl. $\mathrm{Mtg}$., Soc. of Explor. Geophys., Oklahoma Clty, OK (1967).

115. Clarke, D.W. , "General ized Least Squares Estimation of the Parameters of a Dynamlc Model," Proc. Ist IFAC Symp. Identiflcation, Prague (1967).

116. Elsden, C.S. and Ley, A.J., MA Digital Transfer Function Analyser Based on Pul serate Techniques," Automatica, 5, p 235 (1969).

117. Rabiner, L.R. and Rader, C.M., Dlgital Sional Processing, IEEE Press, NY (1972).

118. Ables, J.G., "Maximum Entropy Spectral Analysls," Astro. Astrophys., 15, Pp 383-393 (1974).

119. Daval 1, P.W., "Appl lcations of Statistlics in the Spectral Analysis of Time Varying Systems," Ph.D. Thesis, Univ. of Warwlck, UK (1975).
1?0. Ul rych, T.J. and Blshop, T. M., Maximum Eitropy Spectral Analysis and Autoregressive Dicomposition," Rev. Geophys. Space Phys., 13, p) 183-200 (1975).

131. Fougere, P.F., Zaw al lck, E.J., and Radoski, H. R., "Spontaneous Line Splittling in Miximum Entropy Power Spectrum Analysls, "Phys. Eirth Planet. Intl., 12, PP 201-207 (1976).

1:2. Wellstead, P.E., "Spectral Analysis and Aupl lcations," Control System Centre Rept. No. 4. Secretarlat (1978).

133. Lawrence, P.J. and Rogers, G.J., "Recursive Identification for System Models of Transfar Function Type," Proc. 5th IFAC Symp. on I dent if lcation and System Parameter Estimation, V.l. 1, Pergamon Press, Oxford, PP 283-288 (1979).

124. Wel Istead, P.E., Edmunds, J.M., Prager, D., and Zanker, P., "Self-Tuning Pole/Zero Asslgnment Regulators," Intl. J. Control, 30, p i (1979).

\section{Ilme Domain Papers}

125. Gauss, K.F., Iheorla Metus Cerporum cuelestlum, English Translation: Theory of the Motion of the Heavenly Bodles, Dover, NY, Orig. P.jbl. 1809 (1963).

126. Fisher, R.A., "On an Absolute Griterion for Fitting Frequency Curves," Mess. Math., 41, p 155 (1912).

127. Fisher, R. A., "On the Mathematical Foundations of Theoretical Statistics," Phil. Trans., A-222, p 309 (1921).

128. Plackett, R.L., "Some Theorems in Least Squares," Blometrlca, 37, p 149 (1950).

129. Robbins, H. and Monro, S., "A Stochastic Approximation Method," Ann. Math. Statist., 22, p 400 (1951).

130. Levin, M.J., "Optimum Estimation of Inpulse Response in the Presence of Nolse," IRE Trans. Circult Theory, CT-7, p 50 (1960).

131. Kalman, R.E., "A New Approach to Linear Filtering and Prediction Problems," J. Basic Engrg., Trans. ASME, 82D, PP 35-45 (1960).

132. Kalman, R.E. and Bucy, R.S., "New Results in Linear Filtering and Prediction Theory," J. Easlc Engrg., Trans. ASME, 83D, PP 95-108 (1961).

133. Kendal, M.G. and Stuart, A., The Advanced Iheory of Statistics, Vol. 2, Griffln, London, FP 398-408 (1961). 
134. Mayne, D.Q., "Optimal Nonstatlonary Estimation of the Parameters of a Linear System with Gaussian Inputs," J. Elect. Cont., 14, PP 101-112(1963).

135. Ho. Y.C., "On the Stochastlc Approximation Method and Optimal Filtering Theory," J. Math. Analysls Applications, 6, pp 152-154 (1963).

136. Ho, Y.C. and Lee, R.C.K., "A Bayeslan Approach to Problems in Stochastic Estimation and Control," JACC, Preprint, paper XIV-2 (1964).

137. Ho. B.L. and Kalman, R.E., "Effective Construction of LInear State-Varlable Models from Input/Output Data," Proc. 3rd Ann. Al lerton Conf. Circult and System Theory, PP 449-459 (1965); al so Regel ungstechnlk. 14, Pp 545-548 $(1966)$.

138. Sakrison, D.J., "The Use of Stochastic Approximation to Solve the System Identification Problem," IEEE Trans. on Automatic Control, AC-12, pp 563-567 (1967).

139. Clarke, D.W., "General ized-Least-Squares Estimation of the Parameters of a Dynamic Model," IFAC Symp. on Identification in Auto matlc Control Systems, Prague, Paper 3.17 (1967).

140. Panuska, V., "A Stochastic Approximation Method for Identification of Linear Systems Using Adaptive Filtering," in Prepr ints JACC, Univ. Michigan, p 1014 (1968).

141. Young, P.C., "The Use of Linear Regression and Related Procedures for the Identitication of Dynamic Processes," Proc. 7th IEEE Symp. Adaptive Proc., UaA (1968).

142. Hastings-James, R. and Sage, M.W., "Recursive General lzed Least Squares Procedure for On-Line Identification of Process Parameters," IEEE Proc., pp 2057-2062 (1969).

143. Young, P.C., "An Instrumental Varlable Method for Real-Time Identification of a Nolsy Process," Autanatlca, 6, p 271-287 (1970).

144. Tether, A.J., "Construction of Minimal Linear State-Varlable Models from Finite Input-Output Data," IEEE Trans. On Automatic Control, AC-15, (4), PP 427-436 (1970).

145. SIlverman, L.M., "Real Ization of LInear Dynamical Systems," IEEE Trans. on Autamatic Control, AC-16 (6), PP 554-567 (1971).

146. Kaminskl, P.G., Bryson, A.E.. and Schmidt, S.F., "Discrete Square Root Filtering:
A survey of Current Techniques," IEEE Trans. Automatic Control, AC-16, p 727 (1971).

14". Rossen, R. H. and Lapldus, L., "Minimum Reili ization and System Modeling: I. Fundamenta Theory and Algor ithms," AlChE J.. 18 (4). PP 673-684 (1972).

143. Rossen, R.H. and Lapldus, L., MMinimum Realization and System Modeling: II. Theoretical and Numerical Extensions," AIChE J., 18 (5), pp 881-892 (1972).

149. Talmon, J.L. and van den Boom, A.J.W., "O) the Estimation of Transfer Function Parameters of Process and Nolse Dynamles Using a Single-Stage Estimator," Proc. 3rd IFAC Symp. Idantl fication and System Parameter Estimation, Tha Hague, North-Hol l and (1973).

150. Soderstrom, T., "An On-LIne Al gor Ithm for Approximate Maximum Likel Ihood Identification of Linear Dynamic Systems," Rept. 7308, Dept. Automatic Control, Lund Inst. Tech., Lund, Sweden (1973).

151. Gertler, J. and Banyasz, C. , "A Recurslve (Cn-Line) Maximum Likelihood Identification Method," IEEE Trans. On Automatic Control, $A C-19$, PP 816-820 (1974).

152. Peterka, V.. "A Square Root Filter for Real Time Multivarlate Regression," Kyberneti$k \varepsilon, 11$, p 53 (1975).

153. Young, P.C., "Some Observations on Instrumental Varlable Methods of Time-Serles Aralysls, Intl. J. Control, 23, PP 593-612 (1976).

154. Karny, M., "Probabll Istic ldentification of Self-Reproducing Forms of Distribution Finctions with Order Estimation of the Dynamlc Sy stem," Ph.D. Thesis, inst. Information Theory ald Autanation of the Czechoslorak Academy of Sclences, Prague (1976) (In Czech).

155. Morf, M., Dickinson, B., Kallath. T., and vieira, A., "Efficlent Sol utions of Covarlance Eiluations for Linear Prediction," IEEE Trans. on Acoustic, Speech, and Signal Processing, AisP-25 (5), PP 429-435 (1977).

156. Kung, S., "A New Identification and Model Riduction Al gor ithm Vla Singular Val ue Decomposition," 12th Asilomar Conf. on Circults. Srstems and Computers, Pp 705-714 (1978).

157. Peterka, V., "Bayeslan System IdentifIcation," Proc. 5th IFAC Symp. on Identification and System Parameter Estimation, Darmstadt, Fəd. Rep. Germany, Pergamon Press, Oxforo (1979). 
158. Astrom, K.J., "Maximum Likel Ihood and Prediction Error Methods," Tutor lals on System Identification at the 5th IFAC Symp. on Identiflcation and System Parameter Estimation, Darmstadt, Reprint in Automatica, Special Section (Sept 1980).

159. Lee, D.T.L. and Morf, M., "Recursive Square-Root Ladder EstImation Algor Ithm," IEEE Proc., Intl. Conf. Acoustlc, Speech, and Signal Processing, Denver, $\infty$, pp 1005-1017 (Apr 1980).

160. Peterka, V., "Bayeslan Approach to System Identiflication," in P. Eykhoff (Ed.), Irends and Progress in System Identification, Pergamon Press, Oxford (1981).

161. Ljung, L., "Analysls of a General Recursive Predictor Error Ident If Ication Al gor Ithm," Automatica, 17, pp 89-100 (1981).

162. Sundararajan, N. and Montgomery, R.C.. "Identification of Structural Dynamics Systems Using Least-Square Lattlce Filters," J. Guldance, Control and Dynam., 6 (5), PP 374-381 (1983).

163. Lee, D.T.L., "System Order Determination of ARMA Models Using Ladder Estimatlon Algorithms," J. Astro. Scl., 33 (1), pp 49-61 (Jan-Mar 1985).

164. Montgomery, R. C., and Sundararajan, N., "Identification of the Dynamics of a Two-Dimenslonal Grid Structure Using Least Squares Lattice Fllters," J. Astro. Scl., 33 (1), PP 35-47 (Jan-Mar 1985). 1i55. Wiberg. D.M., "Frequencles of Vibration Estimated by Lattices," J. Astro. Scl. , 33 (i), p. 63-69 (Jan-Mar 1985).

156. Pappe, R.S. and Juang, J.N., "Gal Ileo S sacecraft Modal Identification Using an Eigensistem Real Ization Algor ithm," J. Astro. Scl., 33. (1), pp 15-33 (Jan-Mar 1985).

157. Juang, J.N. and Pappa, R.S., "Effects of Nolse on Modal Parameters Identifled by the Elgensystem Real lzation Algar Ithm," J. Guldaice, Control and Dynam., 9 (3), pp 294-303 $(1986)$.

158. Juang, J.N. and Suzukl, H., "An Elgensystem Realization Algorithm in Frequency Domaln for Modal Parameter Identiflcation," Paper No. 86-2048-CP, A IAA Guldance, Nav Igation and Control Cont., WIIl lamsburg. VA (Aug 18-20, 1986) and J. Vib., Acoust., Stress, Rel. Des., Tans. ASME, 110 (1), pp 24-29 (Jan 1988).

159. Juang, J.N., "Mathematical Correlation of Modal Parameter Identiflcation Methods via System Realization Theory," NASA TM-87720 (Apr $1 \ni 86)$ and Intl. J. Analyt. Exptl. Modal Analysis. 2 (1), pp 1-18 (Jan 1987).

170. Longman, R.W. and Juang, J.N., "A Recursive Form of the Elgensystem Real ization Algorithm for System identification," AIANAAS Astrodynamics Conf.. Williamsburg. VA (Aug 13-20, 1986). 